\title{
New Species, New Combinations, and Lectotypifications in New Caledonian Eugenia L. (Myrtaceae)
}

Author(s): Neil Snow , John W. Dawson, Martin W. Callmander, Kanchi Gandhi \& Jérôme Munzinger Source: Candollea, 71(1):67-81.

Published By: The Conservatory and Botanical Garden of the City of Geneva (CJBG)

DOI: http://dx.doi.org/10.15553/c2016v711a9

URL: http://www.bioone.org/doi/full/10.15553/c2016v711a9

BioOne (www.bioone.org) is a nonprofit, online aggregation of core research in the biological, ecological, and environmental sciences. BioOne provides a sustainable online platform for over 170 journals and books published by nonprofit societies, associations, museums, institutions, and presses.

Your use of this PDF, the BioOne Web site, and all posted and associated content indicates your acceptance of BioOne's Terms of Use, available at www.bioone.org/page/terms of use.

Usage of BioOne content is strictly limited to personal, educational, and non-commercial use. Commercial inquiries or rights and permissions requests should be directed to the individual publisher as copyright holder. 


\title{
New species, new combinations, and lectotypifications in New Caledonian Eugenia L. (Myrtaceae)
}

\author{
Neil Snow, John W. Dawson, Martin W. Callmander, Kanchi Gandhi \& Jérôme Munzinger
}

\begin{abstract}
SNOW,N.,J.W.DAWSON,M.W. CALLMANDER, K. GANDHI \&J.MUNZINGER (2016). New species, new combinations, and lectotypifications in New Caledonian Eugenia L. (Myrtaceae). Candollea 71: 67-81. In English, English and French abstracts. DOI: http://dx.doi.org/10.15553/c2016v711a9

Five new species of Eugenia L. (Myrtaceae) are proposed from New Caledonia: Eugenia amosensis N. Snow, Eugenia homedeboana N. Snow, Eugenia sicifolia J.W. Dawson \& N. Snow, Eugenia tchambaensis J.W. Dawson \& N. Snow, and Eugenia tiwakaensis J.W. Dawson \& N. Snow. The new species are provided with detailed species descriptions, digital images, comments on morphology and ecology, and conservation assessments following IUCN Red List Categories and Criteria. The following new combinations are proposed: Eugenia gomonenensis (Guillaumin) J.W. Dawson \& N. Snow, Eugenia lotoides (Guillaumin) J.W. Dawson \& N. Snow, Eugenia styphelioides (Schltr.) J. W. Dawson \& N. Snow, and Eugenia poimbailensis (Guillaumin) J.W. Dawson \& N. Snow. The new name Eugenia veillonii N. Snow \& Callm. is proposed and its basionym is lectotypified. Lectotypes also are designated for Eugenia mendute Guillaumin, Eugenia ovigera Brongn. \& Gris, Eugenia horizontalis Pancher ex Brongn. \& Gris and its synonym Myrtus aemulans Schltr., as well as for Myrtus gomonenensis Guillaumin, basionym of Eugenia gomonenensis.
\end{abstract}

\section{Résumé}

SNOW, N., J.W. DAWSON, M.W. CALLMANDER, K. GANDHI \& J. MUNZINGER (2016). Nouvelles espèces, nouvelles combinaisons et lectotypifications dans les Eugenia L. (Myrtaceae) de Nouvelle Calédonie. Candollea 71: 67-81. En anglais, résumés anglais et français. DOI: http://dx.doi.org/10.15553/c2016v711a9

Cinq nouvelles espèces d'Eugenia L. (Myrtaceae) sont proposées pour la Nouvelle-Calédonie: Eugenia amosensis N. Snow, Eugenia homedeboana N. Snow, Eugenia sicifolia J.W. Dawson \& N. Snow, Eugenia tchambaensis J.W. Dawson \& N. Snow et Eugenia tiwakaensis J.W. Dawson \& N. Snow. Chacune des nouvelles espèces est présentée avec des descriptions détaillées, des scans numériques, des commentaires sur la morphologie et l'écologie, ainsi que des évaluations du statut de conservation suivant les Catégories et les Critères de la Liste Rouge de l'UICN. Les nouvelles combinaisons suivantes sont proposées: Eugenia gomonenensis (Guillaumin) J.W. Dawson \& N. Snow, Eugenia lotoides (Guillaumin) J.W. Dawson \& N. Snow, Eugenia styphelioides (Schltr.) J.W. Dawson \& N. Snow, et Eugenia poimbailensis (Guillaumin) J.W. Dawson \& N. Snow. Le nouveau nom Eugenia veillonii N. Snow \& Callm. est proposé et son basionyme est lectotypifié. Des lectotypes sont aussi désignés pour Eugenia mendute Guillaumin, Eugenia ovigera Brongn. \& Gris, Eugenia horizontalis Pancher ex Brongn. \& Gris et pour son synonyme Myrtus aemulans Schltr., ainsi que pour Myrtus gomonenensis Guillaumin, basionyme de Eugenia gomonenensis.

\section{Keywords}

MYRTACEAE - Eugenia - New Caledonia - Systematics - Conservation

Addresses of the authors :

NS : Department of Biology, Pittsburg State University, Pittsburg, KS 66762, U.S.A. E-mail: nsnow@pittstate.edu

JWD: School of Biological Sciences, Victoria University of Wellington, P.O. Box 600, Wellington 6140, New Zealand.

MWC: Conservatoire et Jardin botaniques de la Ville de Genève, C.P. 60, 1292 Chambésy, Switzerland.

KG: Harvard University Herbaria, 22 Divinity Avenue, Cambridge, MA, 02138, U.S.A.

JM: Institut de Recherche pour le Développement - Botanique et modélisation de l'architecture des plantes et des végétations (AMAP), 34000 Montpellier, France 


\section{Introduction}

The Myrtaceae are among the most species-rich families of flowering plants in New Caledonia (Dawson 1992, 1999; Morat et al., 2012, IBAnEz et al., 2014). Many species of the family are known from relatively few collections and at least thirty additional new species in four or five genera remain to be described in addition to those proposed here (Snow, unpubl. data).

Among the less studied genera of Myrtaceae for New Caledonia is Eugenia L., one of the largest exclusively woody genera of plants (LucAs et al., 2007; Govaerts et al., 2008; Biffin et al., 2010). The native distribution of Eugenia occurring in both the neo- and paleotropics is unique among the ca. 140-150 genera of Myrtaceae (SNow et al., 2011).

The greatest specific diversity of Eugenia occurs in the neotropics (LANDRUM \& KawASAKi, 1997; Mazine et al., 2014). Areas of particularly high diversity include the Atlantic Coastal forests (Mâta Atlantica) of Brazil, the Caribbean, MesoAmerica (e.g., Barrie 2005, 2009) and the Northern Andes (LANDrum \& KaWASAKi, 1997). The relative paucity of Myrtaceae and Eugenia in lowland Amazonian forests (MorI et al., 1983) may be explained partially by the relatively low stature of many species and their often irregular flowering, which may limit dispersal of fruits, range expansion and diversification rates, although low stature and irregular flowering are not universal characters among species of Eugenia.

In addition to its richness in the New World tropics, Eugenia also has substantial levels of diversity in the paleotropics, particularly in Madagascar (SNow, 2008, 2011; Biffin et al., 2010; Snow et al., 2012, 2015), southern Asia, the Comoros (Byng et al., 2016), and New Caledonia. Given known but unpublished taxa in preparation (e.g., SNow et al., 2015), which includes perhaps 50 additional undescribed species from Madagascar and New Caledonia, we estimate that up to $30 \%$ of the diversity of Eugenia may occur in the paleotropics. Critically from a phylogenetic perspective, the paleotropical diversity in Eugenia appears to reflect a significant part of the known morphological variation in inflorescence morphology, calyx lobe fusion and splitting, flower size, fruit size and testal morphologies, as well as some characters not (yet) known in the neotropics, such as dioecy (VAN WYK \& LOWREY, 1988; BYNG et al., 2016). Inferring the phylogeny of the genus will benefit from proportional sampling across the Old and New Worlds.

Based on revisionary studies currently in progress, Eugenia in New Caledonia appears to comprise approximately sixty species, many of which remain to be described besides those proposed here (Snow et al., unpubl. data). The primary purpose of this paper is to propose five new species in detail, including preliminary conservation assessments following IUCN Red List Categories and Criteria (IUCN, 2012). In addition, we address needed nomenclatural transfers and matters of typification. We have seen all available material at $\mathrm{G}, \mathrm{NOU}$,
MO and P. Terminology largely follows previous recent studies of Eugenia by NS (e.g. SNow et al., 2015) but includes some terminology from BRIGGS \& JoHnson (1979) regarding inflorescence structure and shapes, and other terms following Beentje (2010).

The new species and new combinations proposed here bring the total number of described species of Eugenia in New Caledonia to approximately thirty-five.

\section{New Species}

Eugenia amosensis N. Snow, spec. nova (Fig. 1, 2).

Typus : New Caledonia. Prov. Nord : Col d'Amoss, $20^{\circ} 17^{\prime} 16^{\prime} \mathrm{S} 164^{\circ} 25^{\prime} 42^{\prime} \mathrm{E}, 13 . \mathrm{XI} .2002$, Munzinger et al. 1488 (holo-: P [P00354503 sheet 1, P04884668 sheet 2]!; iso- : MO-5841143! ; NOU [NOU002732]!).

Differing from congeneric species in New Caledonia by its relatively long, narrowly elliptic, sessile to subsessile leaves with cordate bases, cauliflorous inflorescence, and densely velutinous indumentum on the pedicels, hypanthium and proximal abaxial portion of the calyx lobes.

Shrubs to $3 \mathrm{~m}$. Branchlets glabrous, eglandular, smooth, the epidermis soon becoming gray and flaking away. Pedicels, hypanthium and lower calyx lobes densely reddish velutinous. Leaves sessile to sub-sessile, coriaceous, venation brochidodromous, discolorous, surfaces matte, evenly distributed along branchlets. Foliar colleters absent. Leaf blades $15.5-37.7 \times$ 5.0-7.4 cm, narrowly elliptic, base cordate, apex acute, margin flat, secondary and tertiary veins protruding somewhat above; adaxial surface glabrous, midvein raised; abaxial surface moderately to densely glandular (use magnification), secondary and higher-order veins prominent, intramarginal vein prominent, (1.5-)3-5 mm from margin at midpoint of blade. Inflorescences cauliflorous, ca. $2 \mathrm{~cm}$ long, of monads or short (5-flowered) botryoids. Pedicels $2-12 \mathrm{~mm}$, rigid. Bracteoles ca. $0.5 \times$ ca. $1.0 \mathrm{~mm}$ (material scant, possibly not fully expanded), hemispherical, broadly rounded apically. Hypanthium cupuliform, ca. $5 \mathrm{~mm}$. Calyx lobes 4, ca.1-2 mm, dimorphic, apex rounded, more or less glabrous above. Petals 4, 6-7 × 6-7 mm, oblate, sparsely short-ciliate on margins. Stamens numerous (>100), multiseriate; filaments length uncertain (material in bud); anthers ca. $0.8 \mathrm{~mm}$, ellipsoid, dorsifixed, eglandular. Style ca. $6 \mathrm{~mm}$ (limited material), moderately short-villous in lower half, stigma narrow. Ovary bilocular, placentation axile, ovules ca. 25 per placenta, densely but irregularly placed on somewhat triangular-shaped placenta. Fruit unknown.

Distribution, ecology and phenology. - Known only from the type gathering at Col d'Amos (misspelled as "d'Amoss" on the type specimen) near the northern end of Grand Terre (Fig. 2). Flowering in November, fruiting unknown. 


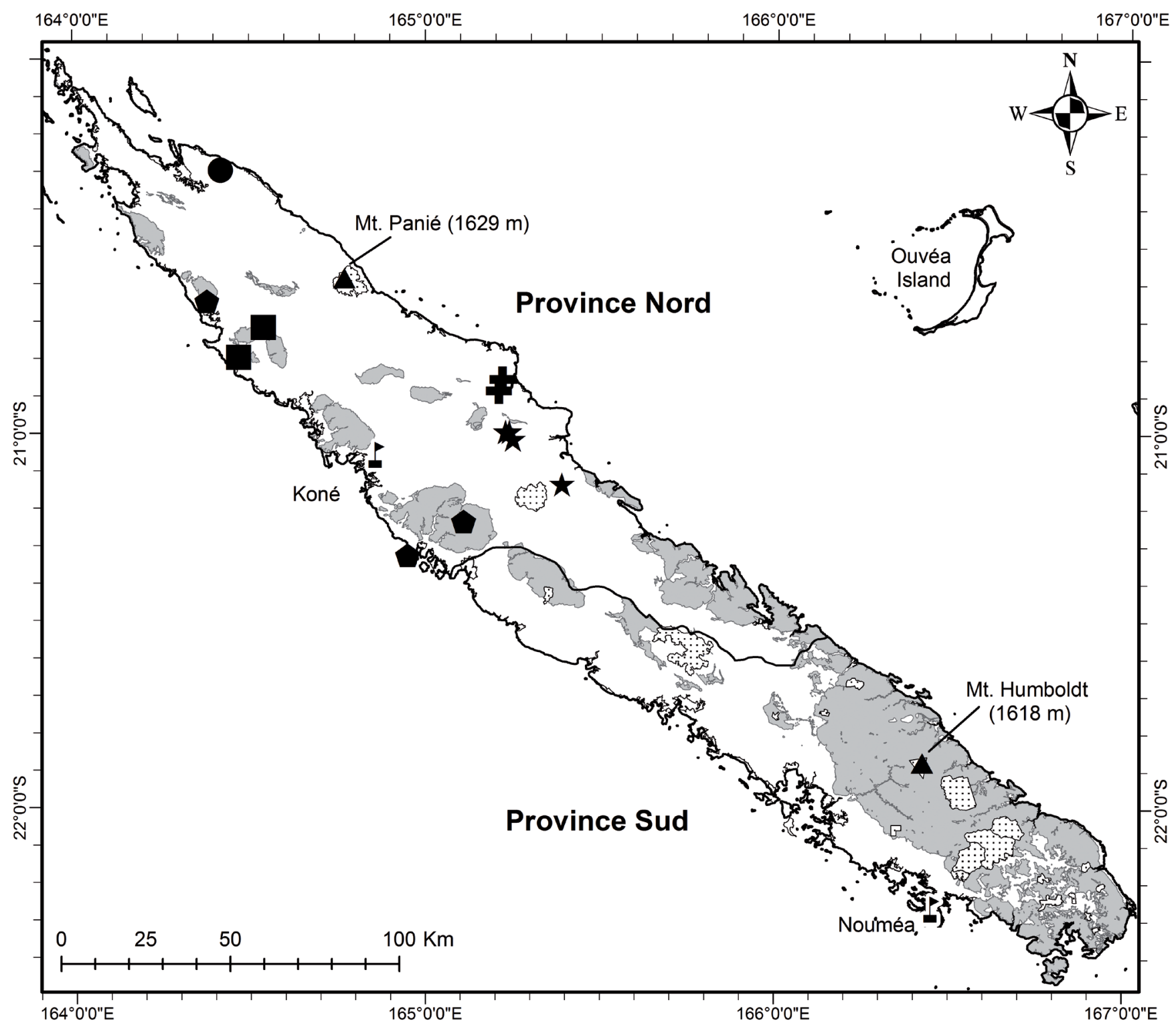

Fig. 1. - Distribution of new species of Eugenia L. in New Caledonia mapped on ultrabasic rocks (light grey) and protected areas (dotted stippling): E. amosensis N. Snow (circle), E. homedeboana N. Snow (squares), E. sicifolia J.W. Dawson \& N. Snow (pentagons), E. tchambaensis J.W. Dawson \& N. Snow (stars), and E. tiwakaensis J.W. Dawson \& N. Snow (crosses). 
Conservation status - With a single location known outside of the protected area network in a forested area heavily fragmented and regularly damaged by anthropogenic bush fires, E. amosensis is assigned a preliminary IUCN conservation status of "Critically Endangered" [CR B2ab(iii, v)+C2(a)+D].

Notes. - Additional collections are needed to better characterize flowering and fruiting material and their seasons. The long, narrowly elliptic, sessile to subsessile cordate leaves, coupled with the cauliflorous inflorescence with dense velutinous indumentum, collectively diagnose the species among others in New Caledonia. Although a subtle character state, the villous base of the style is also atypical for most in the genus.

Eugenia homedeboana N. Snow, spec. nova (Fig. 1, 3).

Typus : New Caledonia. Prov. Nord : Taom, Mt Homedeboa, 800-900 m, 16.X.1969, MacKee 20983 (holo- : P [P06138878]!).

Distinct among congenerics in New Caledonia by the brownish velutinous abaxial leaf surface that turns grayish as the leaf matures, and its sessile clasping ovate leaves.

Shrubs to $1 \mathrm{~m}$. Bark smooth or slightly rough, greyish. Branchlets laterally compressed, reddish-brown (when young) by virtue of short but dense velutinous indumentum. Leaves sessile, stiffly coriaceous, venation brochidodromous, discolorous, surfaces matte, evenly distributed along branchlets. Foliar colleters not seen. Leaf blades $3.5-8 \times 2.5-5 \mathrm{~cm}$, ovate, bases cordate and strongly clasping, apex obtuse, margins somewhat irregularly revolute; adaxial surface appearing glabrous but on close inspection (use high magnification) with moderately dense indumentum of minute, irregularly twisting to somewhat glandular grayish trichomes, midvein flush or slightly and narrowly raised proximally, secondary veins faint, intramarginal vein not visible; abaxial surface like upper surface but indumentum much denser and trichomes dark reddish-brownish when young and becoming grayish, secondary and marginal veins obscured entirely by indumentum. Inflorescences of solitary monads, these ramiflorous towards base of branchlets and axillary. Peduncles rigid, 6-7 mm, densely velutinous. Bracteoles ca. $1.5 \times 1 \mathrm{~mm}$, triangular but obscure (erect and appressed against hypanthium), rigid. Hypanthium cupuliform, ca. $7 \mathrm{~mm}$ long, densely velutinous, pinkish in bud. Calyx lobes 4, distinct in bud, 2.5-3 $\times 2-6 \mathrm{~mm}$ (sometimes much broader than long), broadly rounded to triangular, apex rounded to acute, velutinous abaxially, less so adaxially. Petals 4, 7-9 × 6-8 mm, very widely ovate to oblate, ciliate on margins, white, oil glands faint. Stamens numerous (> 100), multiseriate; filaments up to $4 \mathrm{~mm}$ long, anthers $0.7-1.0 \mathrm{~mm}$, ellipsoid, basifixed, eglandular. Ovary apex densely short-hairy surrounding base of style.
Style (material scant) ca. $5 \mathrm{~mm}$, glabrous; stigma narrow and barely capitate. Fruits 17-20 × 14-18 mm (material limited), asymmetrically sub-ellipsoid (the crowning calyx lobes offset ca. $45^{\circ}$ from axis of petiole), based rounded or tapered and somewhat asymmetrically attached, brown-velutinous.

Distribution, ecology and phenology. - Known only from the northwest on ultramafics and maquis (Fig. 2). Flowering in October and likely into December, fruiting in December.

Conservation status. - The Tsiba locality (MacKee 34497) is included in an ancient mining concession, and the vegetation was mainly cleared in that area, while Mt Homedeboa, the type locality, was severely damaged by fires. Thus, the new species is facing serious threat and with only two locations and an $\mathrm{AOO}$ of $8 \mathrm{~km}^{2}, E$. homedeboana is assigned a preliminary IUCN conservation status of "Endangered" [EN B1ab(ii,iii,v)+2ab(ii,iii,v)].

Notes. - The leaf morphology of E. homedeboana closely resembles that of $E$. virotii Guillaumin, but differs its dense abaxial indumentum. It also resembles E. kaalaensis Guillaumin, which has an identical indumentum of the leaves, but that species is distinctly petiolate.

The type specimen is in flower (although the collection label says the fruits are brown), that of MacKee 34497 is in bud, and Vieillard 2593 bears two fruits.

Paratypi. - New Caledonia. Prov. Nord: Gatope, Vieillard 2593 (P [P04722710]); Ouaco, Tsiba, 400 m, 31.XII.1977, MacKee 34497 (NOU [NOU031553], P).

\section{Eugenia sicifolia J.W. Dawson \& N. Snow, spec. nova} (Fig. 1, 4).

Typus : New Caledonia. Prov Nord: Massif du Boulinda, $400 \mathrm{~m}$, en sous-bois de maquis paraforestier, 23.II.1978, Morat 5947 (holo- : P [P00500636]!; iso- : P [P05094127, P05093915]!).

Differing from New Caledonian congenerics by the combination of sica (dagger-shaped) leaf blades and a densely shortvillous, ferrugineous indumentum on the emerging branchlets, bypanthium, and abaxial calyx lobes.

Shrubs from 1-3 m. Vegetative and floral parts (where present) densely short villous (trichomes ferrugineous; "hairy" henceforth) but becoming more or less glabrous. Branchlets rounded, epidermis becoming flaky. Leaves petiolate, coriaceous, venation brochidodromous, hairy below, dark green when fresh above, much lighter below, surfaces matte or somewhat glossy above, evenly distributed along branchlets. Foliar colleters linear, deep maroon coloured (relatively few 


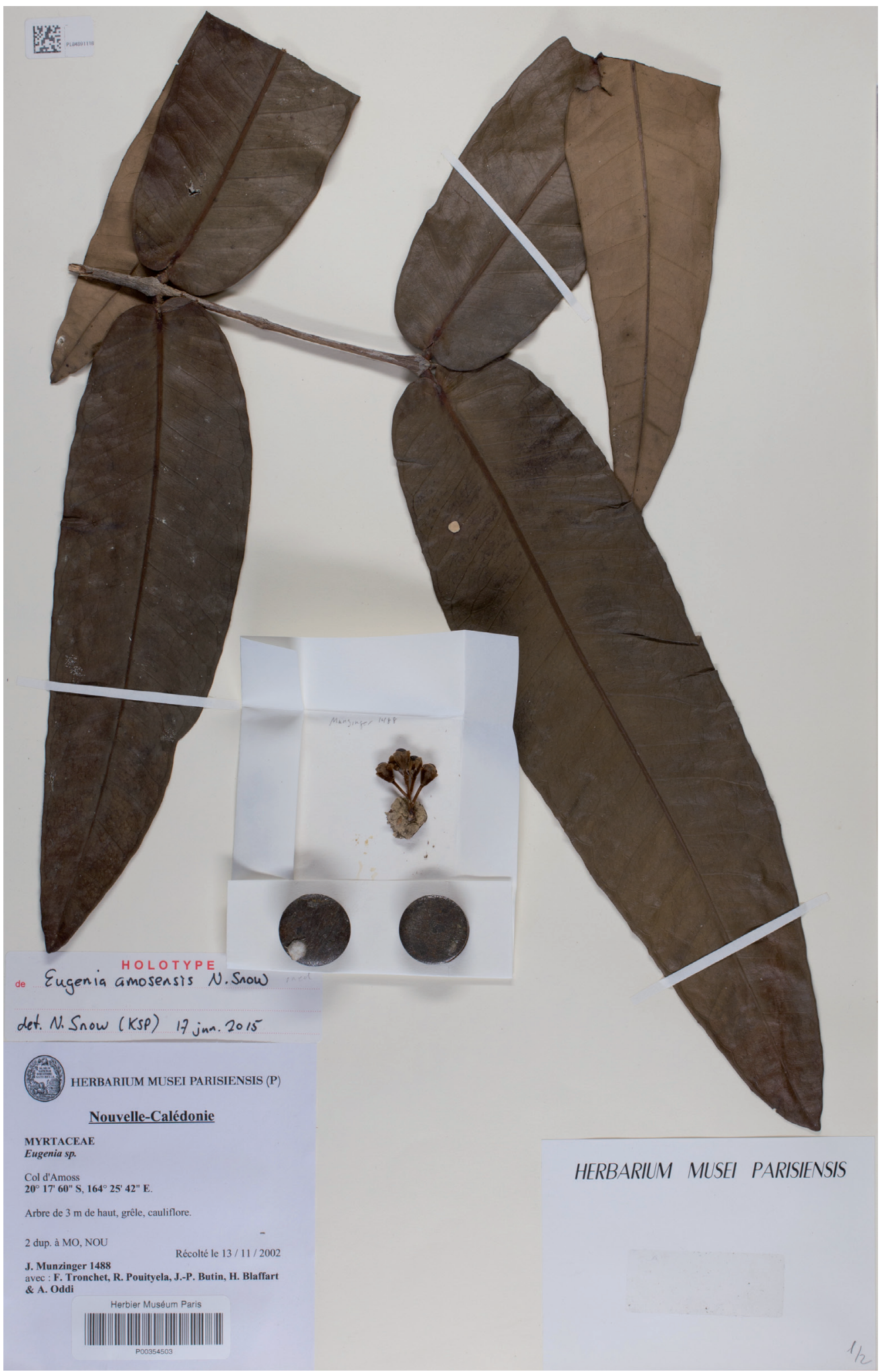

Fig. 2. - Holotype of Eugenia amosensis N. Snow.

[Munzinger et al. 1488, P] [@ Muséum national d'Histoire naturelle, Paris. Reproduced with permission] 


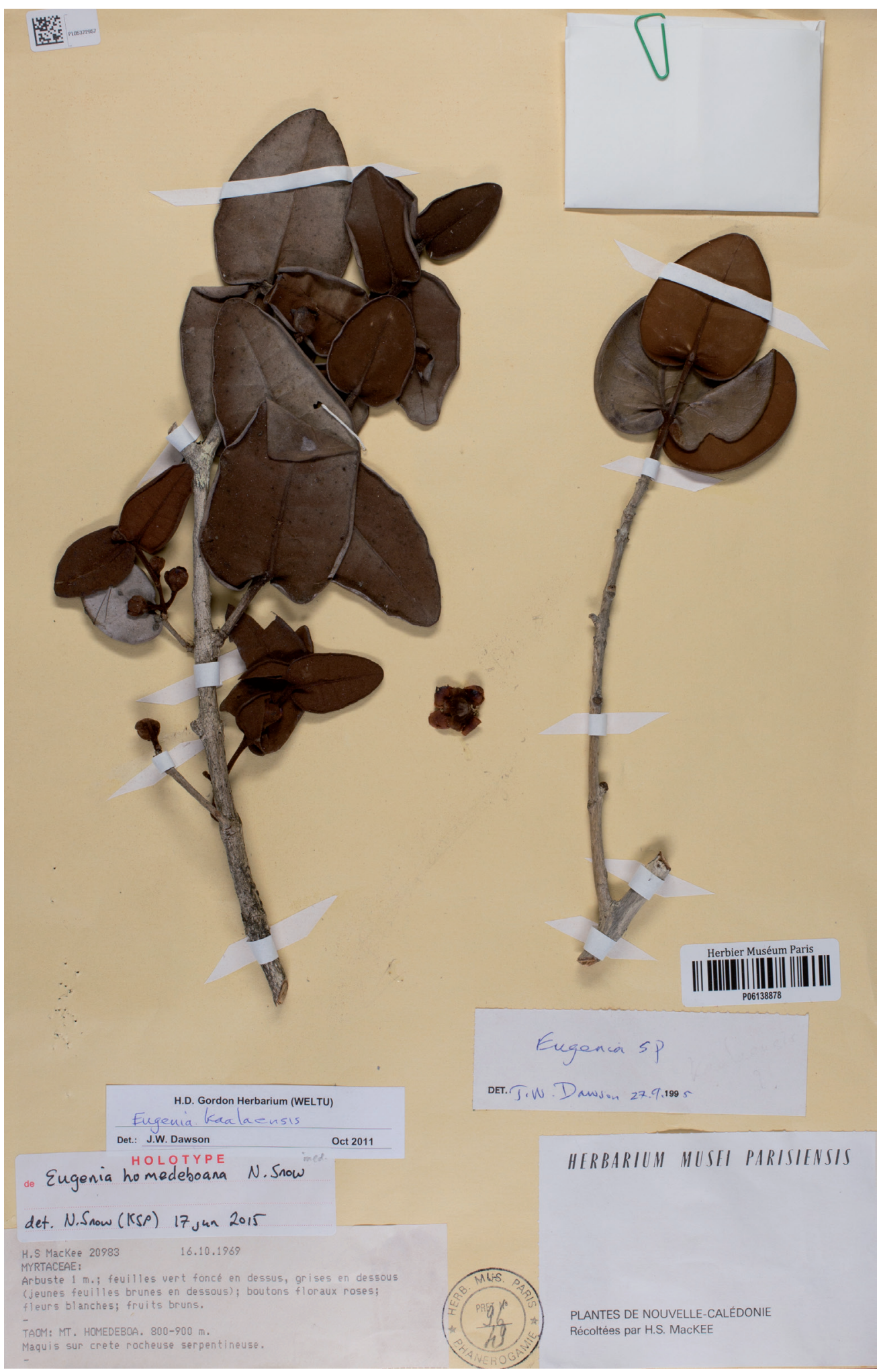

Fig. 3. - Holotype of Eugenia homedeboana N. Snow.

[Mackee 20983, P] [@ Muséum national d'Histoire naturelle, Paris. Reproduced with permission] 


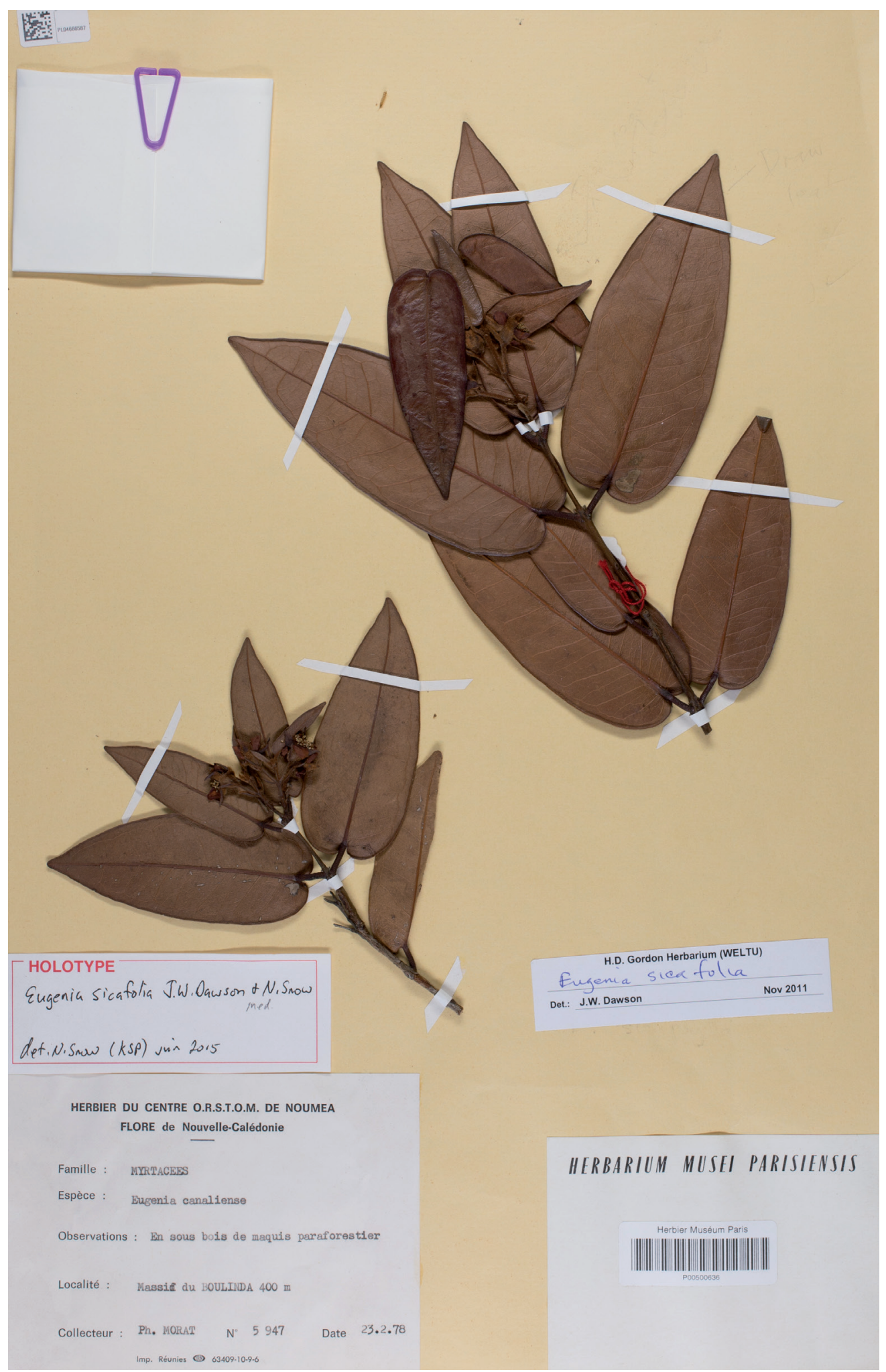

Fig. 4. - Holotype of Eugenia sicifolia J.W. Dawson \& N. Snow.

[Morat 5947, P] [@ Muséum national d'Histoire naturelle, Paris. Reproduced with permission] 
and early-deciduous). Petioles (4-)8-12 mm, terete, surface somewhat transversely rugose, eglandular, hairy. Leaf blades (5.3-)8-13.5 × (2-)3-6.5 mm, narrowly ovate, base cordate the lobes sometimes slightly amplexicaulous relative to petiole, apex acute, margins flat, eglandular, hairy (especially below) but with minute whitish/clear fungal hyphae extruding especially near abaxial midvein (use high magnification with bright light); adaxial midvein flush to slightly sulcate proximally, protruding abaxially; secondary veins indistinct adaxially, obscure to moderately prominent abaxially; lateral vein obscure to prominent, ca. $2-3.5 \mathrm{~mm}$ from margin at midpoint of blade. Inflorescence a bracteate raceme or single flower, axillary, supraxillary or terminal, axis densely hairy, pinkish to light maroon (when fresh). Peduncles 6-12 mm, rigid, ascending, hairy. Bracteoles (3.5-)5-7 $\mathrm{mm}$ (the apex extending slightly beyond base of calyx lobes), linear to very narrowly ovate, rigid, ascending to erect, leaf-like (midvein and secondary veins faintly visible), hairy. Hypanthium 5$6 \mathrm{~mm}$, campanulate, hairy and remaining so during anthesis. Calyx lobes 4, (4.5-)5-7 mm, triangular, apex acute, hairy and sometimes remaining so (especially abaxially). Petals 4, 4.5-5 $\times 3.5-4 \mathrm{~mm}$, very widely ovate to oblate, based round to truncate, whitish, ciliate on margins, oil glands sparse. Stamens numerous ( $>150)$, whitish or cream-coloured; staminal disk glabrous; filaments 2-4 mm; anthers 0.6-0.9 mm, ellipsoid, basifixed, eglandular. Ovary apex glabrous. Styles ca. $3 \mathrm{~mm}$, glabrous, stigma terete (scarcely if at all capitate). Ovary bilocular; placentation axile; ovules numerous. Fruits 15$18 \mathrm{~mm} \times 12-17 \mathrm{~mm}$, globose, base rounded or slightly tapered, calyx lobes appressed to fruit or somewhat ascending.

Etymology. - The specific epithet is derived from the Latin elements sica ("dagger") and folia (leaf), in reference to the shape of the leaf blades.

Distribution, ecology and phenology. - Known from four collections in the north-west, at $400 \mathrm{~m}$ on Mt. Boulinda and $20 \mathrm{~m}$ on Pindai (Fig. 2). The species occurs in maquis or "paraforestier" vegetation over ultramafic or calcareous soils and sclerophyllous forests in Pindaï. Flowering in February, fruiting in March and April.

Conservation status. - The two known locations (Boulinda, Pindai) are both outside mining concessions, but the vegetation in the Boulinda is fragmented due to mining activities. Giving the restricted distribution of the new species, an $\mathrm{AOO}$ of only $4 \mathrm{~km}^{2}$ and two known locations, E. sicifolia is assigned a preliminary IUCN conservation status of "Endangered" [EN B1ab(i,ii,iii,v)+2ab(i,ii,iii,v)].
Note. - The narrowly ovate leaves with their acute apices, deeply cordate bases and prominent petioles, coupled with the dense indumentum on emerging growth and portions of the flower, are diagnostic.

Paratypi. - New Caledonia. Prov. Nord: Pindaï, 26.IV.2007, Hequet (leg. Butin) 3677 (NOU [NOU018421]); Baie des Sapins, Pindaï, 18.VII.2007, Hequet (leg. Butin) 3727 (NOU [NOU022012]); Pindaï, ca. 20 m, 16.XII.1998, Veillon (leg. Butin) 8189 (NOU [NOU073564]); Pindaï, 66 m, 15.IV.2013, Lebouvier NL113 (NOU); ibid. loc., 16.IV.2014, Lebouvier NL144 et al (NOU).

Eugenia tchambaensis J.W. Dawson \& N. Snow, spec. nova (Fig. 1, 5).

Typus : New Caledonia. Prov. Nord: Haute vallée de la Tchamba, 350 m, 16.V.1984, Veillon 5691 (holo-: $\mathrm{P}$ [P04722505]!; iso- : NOU [NOU031551]!, MPU [MPU026760]).

Differing from congeneric species in New Caledonia by relatively long, thin, often erect pedicels, relatively short sessile leaves, and distinctly raised midrib of the adaxial leaf surface.

Shrubs 1.3-4 meters. Branchlets glabrous, laterally compressed on emergence, becoming terete. Leaves sessile and clasping stem, coriaceous, venation brochidodromous, glabrous, discolorous, surfaces matte, evenly distributed along branchlets. Foliar colleters absent. Leaf blades (2.0-)4.0-11.4 × (1.3-)2.8$6.0 \mathrm{~cm}$, elliptic, base cordate and slightly conduplicate basally, apex obtuse, margin flat but surface irregularly sinuous; adaxial surface glabrous, eglandular or faintly glandular (use magnification), midvein raised in lower half of blade and sometimes nearly to the apex; abaxial surface glabrous, eglandular, secondary veins indistinct, intramarginal vein indistinct, 0.5 $1.5 \mathrm{~mm}$ from margin at midpoint of blade. Inflorescences terminal, axillary, or occasionally ramiflorous, flowers solitary flowers or occasionally in fascicles. Pedicels (14-)20-45 mm, narrow ( $<1 \mathrm{~mm}$ wide) but rigid, glabrous, densely glandular, often steeply ascending to nearly erect. Bracteoles 1-1.5 mm, narrowly triangular to triangular, glabrous, glandular, rigid, typically reflexed at $90^{\circ}$ angle, persistent in fruit. Hypanthium ca. $2 \mathrm{~mm}$ long, cupuliform, glabrous, densely glandular. Calyx lobes 4, 1$2 \mathrm{~mm}$ initially but tearing radially during anthesis and becoming up to $5 \mathrm{~mm}$, broadly rounded, glabrous above and below. Petals 4, 3.5-5 $\times 3-4 \mathrm{~mm}$, oblate, minutely ciliate on margin, whitish, glandular. Stamens ca. 75-100, multiseriate. Filaments length unknown; anthers $0.5-0.7 \mathrm{~mm}$, globular to sub-ellipsoid, subbasifixed, eglandular. Styles 3-4 mm, glabrous, narrowly capitate. Fruit 9-17 × 14-20 mm, subglobose to subcylindrical, rounded or sometimes asymmetrical at base, glabrous, densely glandular (glands small), green (fresh) turning nearly black when dried. 


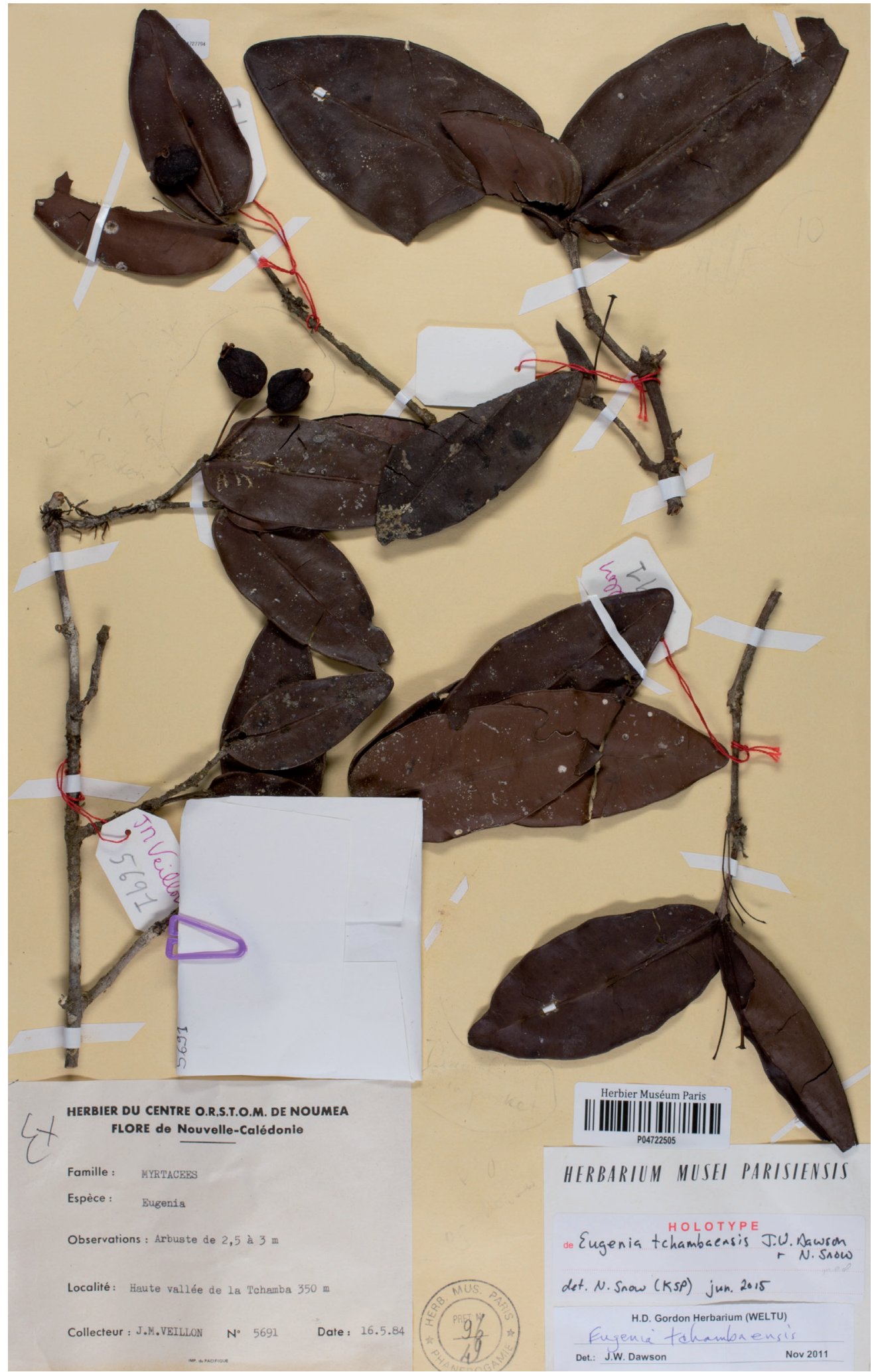

Fig. 5. - Holotype of Eugenia tchambaensis J.W. Dawson \& N. Snow.

[Veillon 5691, P] [@ Muséum national d'Histoire naturelle, Paris. Reproduced with permission] 
Distribution and ecology. - Known from Tchamba, and vicinity from 350 to ca. 500 meters in humid forest over schistes or graywackes (Fig. 2). Flowering confirmed for January, fruiting January through July.

Conservation status. - The $\mathrm{AOO}$ and $\mathrm{EOO}$ is estimated to be $16 \mathrm{~km}^{2}$ with two locations (Haute-Tchamba and ridge between Haute-Monéo and Mou), none in a protected area. Logging is no longer active in that area, E. tchambaensis is therefore assigned a preliminary IUCN conservation status of "Vulnerable" [VUD2].

Notes. - The relatively short sessile leaves with distinctly raised upper midribs and relatively long, thin, and often erect pedicels collectively are diagnostic. The MacKee specimen occurs at higher elevations ("600-700 m") and has shorter leaves than the other specimens, but it otherwise accords in all other features.

Paratypi. - New Caledonia. Prov. Nord: Vallée de la Tchamba, $21^{\circ} 00^{\prime 2} 20^{\prime} \mathrm{S}, 165^{\circ} 14^{\prime} 02^{\prime} \mathrm{E}, 520 \mathrm{~m}, 13 . \mathrm{I} .2009$, Barrabé et al. 834 (NOU [NOU033931], P [P04681808]); Upper Tchamba River valley, Pondië forest, along road to Wâo Uni, 21 00'25”S 165'14'27”E, 500 m, 27.IV.2002, Lowry et al. 5684 (MO, P [P04884671]); Ponerihouen, crête entre Haute Mou et Haute Monéo, 21.VI.1973, MacKee 26836 (P [P04722504]); Haute Tchamba, 2100'18”S 165'13'53”E, 17.VII.2004, Munzinger et al. 2244 (NOU [NOU006487], P [P04884649]).

\section{Eugenia tiwakaensis J.W. Dawson \& N. Snow, spec. nova} (Fig. 1, 6).

Typus: New Caledonia. Prov. Nord: Basse Tiwaka, 10 m, 1.I.1979, MacKee 36340 (holo- : P [P04722500]!).

Distinct among congenerics in New Caledonia by its cordate to basally rounded, petiolate leaves, secondary veins arising from ca. $10-20^{\circ}$ angles, glandular abaxial leaf surfaces, raised adaxial midrib, and sparsely to moderately densely short-villous ferrugineous indumentum of the inflorescence axis and flowers.

Shrubs to $2 \mathrm{~m}$. Indumentum (where present) ferrugineous, sparsely to moderately short-villous ("hairy" below). Branchlets rounded to slightly compressed, moderately to densely short-villous (trichomes ferrugineous at base but often clear or whitish apically), the epidermis sometimes slightly furrowed longitudinally and soon becoming flaky. Leaves petiolate, coriaceous, venation brochidodromous, glabrescent, slightly discolorous, surfaces matte or somewhat glossy above, evenly distributed along branchlets. Foliar colleters not seen. Petioles 4-7 mm, sulcate above, eglandular. Leaf blades 10.0-14.6 $\times$ $3.5-5.7 \mathrm{~cm}$, narrowly elliptic to narrowly ovate, base rounded or cordate, apex acute, margin flat; adaxial surface glabrescent near base but otherwise glabrous, eglandular, midvein narrowly and slightly projecting proximally but becoming flush distally, secondary and tertiary veins prominent and slightly projecting (dried material); abaxial surface glabrous, oil glands common and distinct; secondary veins prominent, intramarginal vein prominent and 3-6 $\mathrm{mm}$ from margin at midpoint of blade (also visible adaxially). Inflorescences terminal, axillary or ramiflorous; flowers solitary, paired, fascicled, or in short brachyblasts. Peduncles 4-12 mm, rigid, more or less ascending, hairy. Bracteoles 2, 1.0-1.2 mm, triangular, ascending to erect and appressed against hypanthium, glandular above, hairy, soon deciduous. Hypanthium 3-4 mm, obconic, prominently glandular, sparsely to moderately hairy. Calyx lobes 4, 2-3 mm, broadly rounded, prominently glandular, ciliate and sparsely hairy below. Petals 4, 5-9 $\times 3-5 \mathrm{~mm}$, obovate, sparsely short ciliate, glands sparse. Stamens ca. 75-125, multiseriate; filaments 5-8 mm; anthers 1.0-1.2 mm, globose to subellipsoid, sub-basifixed, eglandular; staminal disc short-villous. Ovary apex (surrounding style) glabrous. Style length not confirmed (but glabrous below). Fruit not seen but said to be reddish.

Distribution and ecology. - Eugenia tiwakaensis at present is known only from two collections near the northwest coast, growing in a transitional zone between schistes and serpentines or over ultramafics from ca. $10 \mathrm{~m}$ to an unspecified "middle altitude" (Vandrot 629) on Tiwaka (Fig. 2). Flowering in January, fruiting in September.

Conservation status. - The recent collection (Vandrot 629) indicates the species is a common local shrub in a very small patch of remnant forest of ca. 2,931 ha. on a plateau that was nearly completely burned. The MacKee locality "basse Tiwaka, $10 \mathrm{~m}$ " is vague, but this general area has been burned widely and intentionally during political protests over the past 35 years. With only three recent collections from a single reliable location in a highly threatened forest remnant, E. tiwakaensis is assigned a preliminary IUCN conservation status of "Critically Endangered" [CR B1ab(v)+2ab(v) +2(a) +D].

Notes. - Eugenia tiwakaensis most closely resembles E. sicifolia, although the triangular bracteoles and broadly rounded calyx lobes of E. tiwakaensis differ from the linear and proportionally longer bracteoles and acute calyx lobes of E. sicifolia. A note on the holotype label indicates the plant was frequented by bees.

Paratypus. - New Caledonia. Prov. Nord: Tiwaka, Plateau de Kokingone, 29.IX.2012, $165^{\circ} 13$ '57”E 20 51'35”S, 365 m, Vandrot 629 (NOU [NOU079951], P [P02089724]). 


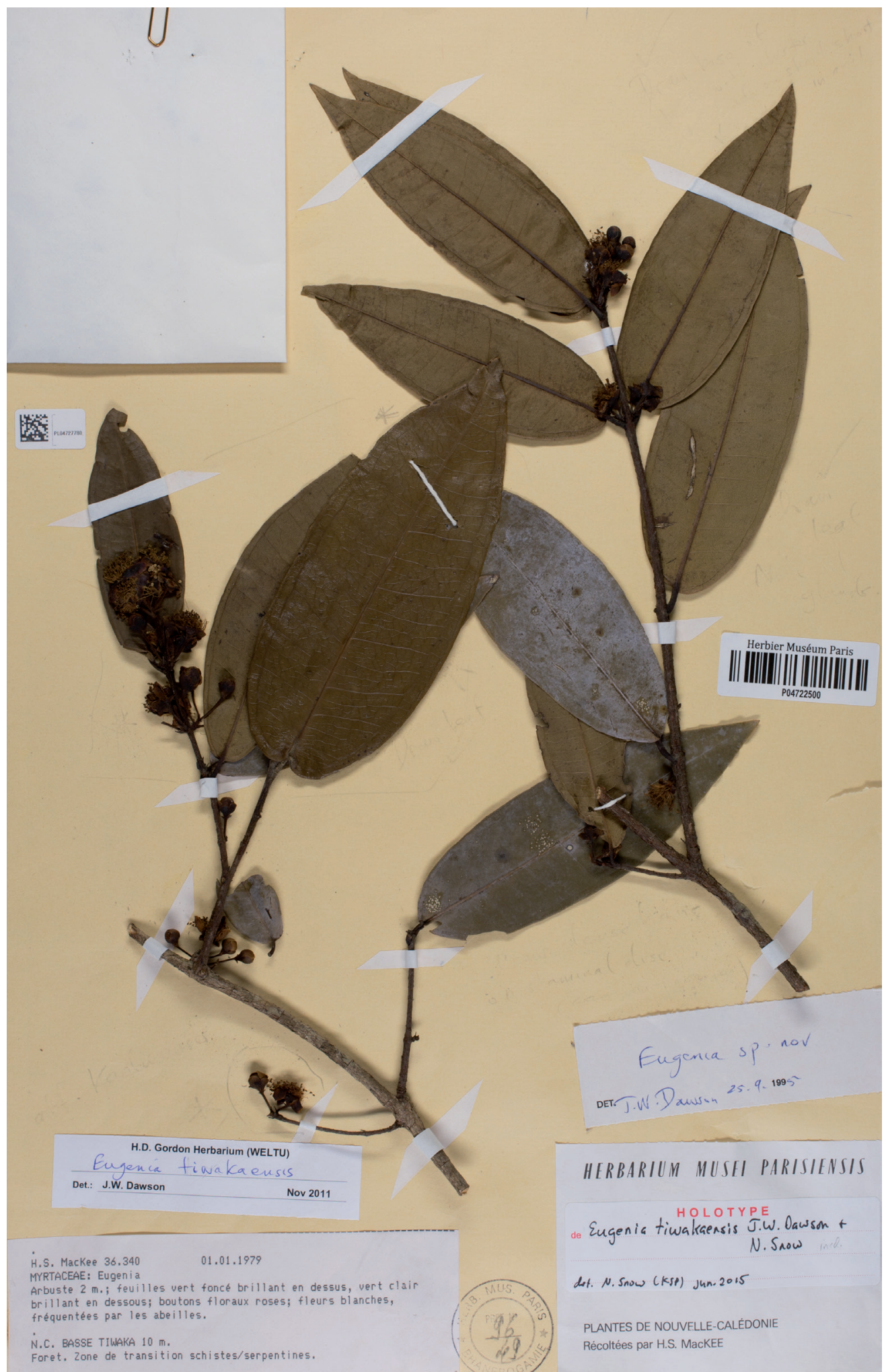

Fig. 6. - Holotype of Eugenia tiwakaensis J.W. Dawson \& N. Snow.

[Mackee 36340, P] [@ Muséum national d'Histoire naturelle, Paris. Reproduced with permission] 


\section{New combinations, a new name, and lectotypifications}

Eugenia gomonenensis (Guillaumin) J.W. Dawson \& N. Snow, comb. nova.

$\equiv$ Myrtus gomonenensis Guillaumin in Bull. Soc. Bot. France $85: 631.1939$.

= Uromyrtus gomonenensis (Guillaumin) Burret in Notizbl. Bot. Gart. Berlin-Dahlem 15 : 493. 1941.

$\equiv$ Austromyrtus gomonenensis (Guillaumin) Burret in Notizbl. Bot. Gart. Berlin-Dahlem 15 : 493. 1941.

Lectotypus (here designated) : New Caledonia. Prov. Nord: Collines de Gomonen, Gatope, s.d., Vieillard 2615 (P [P00500633]!). Syntypus : New Caledonia. Prov. Nord: Montagnes de Gatope, Vieillard 2620 (P, not found).

Notes. - The protologue of Myrtus gomononensis included two syntypes (Guillaumin, 1939); Vieillard 2615 is chosen over Vieillard 2650 because the other syntype was not found at P. Burret (1941: 493) made combinations for both Uromyrtus Burret and Austromyrtus Burret, reflecting his uncertainty into which genus the taxon ultimately should be placed.

Eugenia horizontalis Pancher ex Brongn. \& Gris in Bull. Soc. Bot. France 12: 179. 1865.

Lectotypus (here designated) : New Caledonia. Prov. Sud : Port-de-France, 1855-1860, Vieillard 512 (P [P00637576]!; isolecto-: P [P00543870]!). Syntypus : NEW Caledonia : sine loc., 1862, Pancher s.n. (P [P06670059, P00696289, P00696290]!); Balade, 1855-1860, Vieillard 513 (P [P00637577]!).

$=$ Myrtus aemulans Schltr. in Bot. Jahrb. Syst. 40 (Beibl. 92) : 29. 1908. Lectotypus (here designated) : New Caledonia. Prov. Sud : Dumbea, Le Rat 46 (P [P00543869]!).

Notes. - The three syntypes mentioned in the protologue for Eugenia horizontalis are represented by six sheets at P. Although the selected lectotype, Vieillard 512, has limited flowering material, it is representative of the species.

The holotype of Myrtus aemulans has been destroyed at $\mathrm{B}$ and the isotype at $\mathrm{P}$ is here designated as the lectotype.

As currently recognized, Eugenia horizontalis has glabrous, more or less pendulous flowers arising from elongated, slender pedicels. The species is restricted to the leeward side of New Caledonia in the southcentral part of the island in sclerophyllous forest or maquis. It is one of several species with significantly reduced flowers and leaves.
Eugenia lotoides (Guillaumin) J.W. Dawson \& N. Snow, comb. nova.

$\equiv$ Myrtus lotoides Guillaumin in Bull. Soc. Bot. France 85 : 632. 1939.

$\equiv$ Austromyrtus lotoides (Guillaumin) Burret in Notizbl. Bot. Gart. Berlin-Dahlem 15: 504. 1941.

Typus : New Caledonia. Prov. Nord: Montagnes de Oua Tendé près Gatope, 1861-1867, Vieillard 2616 (holo- : P [P02428351]!; iso :- P [P00543872]!).

Note. - Eugenia lotoides is one of several species with small leaves and flowers. As currently understood, specimens often have three leaves per node.

Eugenia mendute Guillaumin in Bull. Soc. Bot. France 85 : 638. 1939.

$\equiv$ Austromyrtus mendute (Guillaumin) Burret in Notizbl. Bot. Gart. Berlin-Dahlem 15 : 505. 1941.

Lectotypus (here designated): New CaLedonia. Prov. îlesLoyauté: Lifou, VII.1869, Balansa 2083 (P [P02428359]!; isolecto-: P [P00543864, P00543865]!). Syntypi : NEW Caledonia. Prov. îles-Loyauté : am Ostrand des Plateau, Ouvéa, 7.VIII.1925, Däniker 1969 (Bogen 2) (Z [Z-000092725] image seen); an der Ostküste von Ouvéa, 22.IX.1925, Däniker 1969 (Bogen 1) (Z [Z-000092724] image seen); Südküste von Muli, Ouvéa, 3.X.1925, Däniker $1969 a$ (Z [Z-000092727] image seen); am Cap Bernard auf Lifou, 2.XI.1925, Däniker 1969b (Z [Z-000092726] image seen); Lifou, comm. 1861, Deplanche 7 (P [P00543866, P00696288]!).

Notes. - Five syntypes are cited in the protologue, three of which were collected by Albert Ulrich Däniker (1894-1957) that are deposited at Z. One if these collections, Däniker 1969 clearly represent two gatherings collected at different dates and localities and is here cited as two separate syntypes, making a total of five remaining syntypes. The designated lectotype [P02428359] has mature or nearly mature fruits, whereas the indicated isolectotypes at $\mathrm{P}$ are sterile [P00543864, P00543865].

Eugenia ovigera Brongn. \& Gris in Bull. Soc. Bot. France 12: 179. 1865.

$\equiv$ Calycorectes ovigera (Brongn. \& Gris) Guillaumin in Bull. Mus. Natn. Hist. Nat. 25 : 503. 1919.

$\equiv$ Stereocaryum ovigerum (Brongn. \& Gris) Burret in Notizbl. Bot. Gart. Mus. Berlin-Dahlem 15: 547. 1941.

Lectotypus (here designated) : New Caledonia. Prov. Sud: Bord de la Rivière d'Unia, 1855-1860, Vieillard 473 (P [P00402692]! ; isolecto- : P [P00402773, P00402774]!). Syntypus : New Caledonia. Prov. Sud : île des Pins, 1861, Pancher s.n. (P [P00402713]!) 
Notes. - The two syntypes indicated in the protologue are represented by four sheets at P. Although the selected lectotype has only one mature fruit, it exhibits the floral and young fruiting morphology.

Eugenia ovigera is one of several species in New Caledonia in which the calyx lobes split radially during anthesis towards and often beyond the staminal disc.

\section{Eugenia poimbailensis (Guillaumin) J.W. Dawson \& N. Snow, comb. nova. \\ $\equiv$ Myrtus poimbailensis Guillaumin in Bull. Soc. Bot. France 85: 633.1939. \\ $\equiv$ Austromyrtus poimbailensis (Guillaumin) Burret in Notizbl. Bot. Gart. Berlin-Dahlem 15 : 505. 1941.}

Typus : New Caledonia. Prov. Nord: Wagap, bord des torrents à «Poimbeilla», 1861-1867, Vieillard 2605 (holo- : $\mathrm{P}[\mathrm{P} 00632556] !)$.

Note. - The 4-merous flowers, globular seeds, dibrachiate hairs on the emerging foliage, and the relatively new understanding that Myrtus L. is confined to Europe and North Africa (SNow et al., 2003), support the transfer of this taxon into Eugenia.

Eugenia styphelioides (Schltr.) J.W. Dawson \& N. Snow, comb. nova.

$\equiv$ Myrtus styphelioides Schltr. in Bot. Jahrb. Syst. 40 (Beibl. 92): 31. 1908.

$\equiv$ Austromytrus styphelioides (Schltr.) Burret in Notizbl. Bot. Gart. Berlin-Dahlem 15 : 504. 1941.

Lectotypus (here designated) : New CALEdonia. Prov. Sud : Bord Dumbea, Le Rat E̋ Le Rat 166 (P [P00637568]!).

Note. - The holotype of Myrtus styphelioides has been destroyed at $\mathrm{B}$ and the isotype at $\mathrm{P}$ is here designated as the lectotype.

Eugenia veillonii N. Snow \& Callm., nom. nov. (Fig. 7).

$\equiv$ Spermolepis rubiginosa Brongn. \& Gris in Bull. Soc. Bot. France 10: 577.1863 [non Eugenia rubiginosa Cambess. in A. St.-Hil., Fl. Bras. Merid. 2: 338. 1832].

$\equiv$ Schizocalyx rubiginosa (Brongn. \& Gris) Brongn. \& Gris in Ann. Sci. Nat., Bot., sér. 5, 13: 380. 1871.

$\equiv$ Calycorectes rubiginosus (Brongn. \& Gris) Guillaumin in Not. Syst. (Paris) 2:131. 1911.

$\equiv$ Stereocaryum rubiginosum (Brongn. \& Gris) Burret in Notizbl. Bot. Gart. Mus. Berlin-Dahlem 15:546.1941.

$\equiv$ Myrtomera rubiginosa (Brongn. \& Gris) B. C. Stone in Pacific Sci. 16: 241. 1962.
Lectotypus (here designated): New Caledonia: sine loc., 1862, Pancher s.n. (P [P00637569]!).

Notes. - The only gathering mentioned within the protologue for Spermolepis rubiginosa is: "hab. in collibus ferrugineis Novae Caledoniae (Pancher, 1862)” (Brongnart \& GRIs, 1863: 577). Even though several collections by Pancher are deposited at $\mathrm{P}$, only two of them are dated 1862 [P00402683, P00637569]. Of these two specimens, the latter [P00637569] shows the habitat as "coteaux ferrugineux", which closely matches the prologue information, and thus can reasonably be considered as the holotype. This assessment is strengthened by the fact that Brongniart and Gris were working in P. However, some authors might consider the protologue citation as insufficient to consider this specimen [P00637569] as the holotype as discussed below.

Within the protologue, Brongniart and Gris did not mention "Pancher, 1862" at P as being most representative. Since two Pancher specimens at $\mathrm{P}$ show the date 1862, one may argue that there is no evidence that the two specimens belong to two gatherings, that it is uncertain that Brongniart and Gris based their new species only on P00637569 specimen alone, and that therefore, a lectotype designation is needed (McNeILL et al. 2014). Because of the uncertainty, we designate the P00637569 specimen as the lectotype, and at the same time we do not rule out the possibility that it could be a holotype.

Eugenia veillonii was described by Brongniart \& Gris in what they believed was a new genus: Spermolepis Brongn. \& Gris 1864 (non Raf. 1825). Later, they transferred the preceding species to Schizocalyx O. Berg 1856 (non Scheele 1843). Subsequently Guillaumin transferred the species into the neotropical genus Calycorectes O. Berg because of the fused calyx lobes associated with that genus (see LANDrUM \& KAWASAKI, 1997).

No preliminary molecular data are available for species of Eugenia in New Caledonia that have the splitting calyx lobes typical of E. vieillonii (Fig. 7). However, preliminary phylogenetic studies show Calycorectes to be nested within Eugenia s.l. (Lucas et al., 2007; MAZINE et al., 2014), the members of which also have fused calyx lobes that split during anthesis. This character likely has arisen in parallel, given that it recurs in the Malagasy E. ambanizanensis N. Snow (Snow, 2008), another undescribed species from Madagascar (Snow, ined.), several in the Mascarenes described initially in Monimiastrum J. Guého \& A.J. Scott by ScotT (1980) but transferred later into Eugenia (SNOw, 2008), and the recently described Eugenia rara Rigueira \& Sobral from Brazil (Sobral et al., 2015).

A new name is needed because the epithet rubiginosa is unavailable in Eugenia. The new epithet "vieillonii" honours our colleague Jean-Marie Veillon (b. 1939). Jean-Marie is an expert on the flora of New Caledonia and has made over 8000 collections from the Island. His numerous works, including two volumes of the "Flore de Nouvelle-Calédonie et Dépendances", have contributed significantly towards overall progress on the knowledge of New Caledonia's flora. 


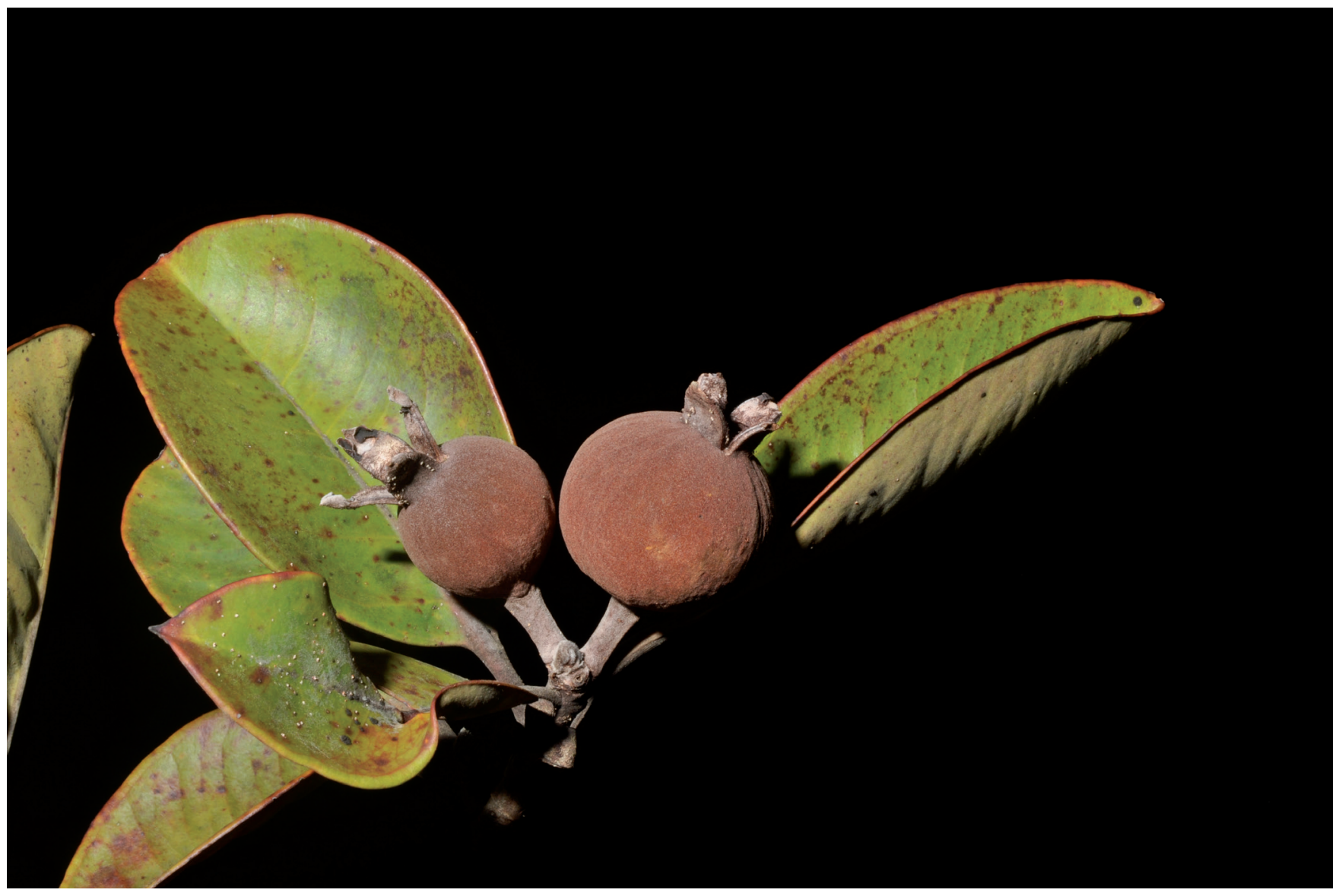

Fig. 7. - Fruiting plant of Eugenia veillonii N. Snow \& Callm.

[Callmander et al. 1241] [Photo: P. Lowry]

\section{Acknowledgements}

We thank Odile Poncy and Pete Lowry for coordinating and assisting with research visits and preparation of loans at the Muséum national d'Histoire naturelle in Paris. Support to the first author to work in Paris in 2015 was provided by the Muséum National d'Histoire Naturelle and from a Summer Research Fellowship from Graduate and Continuing Education at Pittsburg State University in Kansas. We thank the Curators at $\mathrm{G}, \mathrm{MO}, \mathrm{NOU}$ and $\mathrm{P}$ for access to specimens. NS thanks Mathieu Donnat (P) for assistance processing and annotating specimens and organizing large amounts of material for exchange and loans. We also thank Pete Lowry for the nice photo of Fig. 7 and the Red List Authority (RLA) in New Caledonia, especially Stéphanie Chanfreau and Vincent Tanguy, for advice on the conservation status assessments. Finally, we thank Peter Wilson and an anonymous referee for their careful reviews.

\section{References}

Barrie, F.R. (2005). Thirty-five new species of Eugenia (Myrtaceae) from Mesoamerica. Novon 15: 4-49.

Barrie, F.R. (2009). Eugenia L. In: Davidse, G. et al. (ed.), Fl. Mesoamericana 4(1): 81-129. Universidad Nacional Autónoma de México.

Beentje, H. (2010). The Kew plant glossary: An illustrated dictionary of plant terms. Royal Botanic Gardens, Kew.

Biffin, E., E.J. Lucas, L.A. Craven, I.R. da Costa, M.G. HarRINGTON \& M.D. CRISP (2010). Evolution of exceptional species richness among lineages of fleshy-fruited Myrtaceae. Ann. Botany (Oxford) 106: 79-93.

Briggs, B.S. \& L.A.S. Johnson (1979). Evolution in the Myrtaceaeevidence from inflorescence structure. Proc. Linn. Soc. New South Wales 102: 157-256.

Burret, M. (1941). Myrtaceen-Studien. Notizbl. Bot. Gart. BerlinDablem 15: 479-550. 
Byng, J.W., F. Barthelat, N. Snow \& B. Bernardini (2016). A revision of Eugenia and Syzygium (Myrtaceae) from the Comoros. Phytotaxa 242: 163-184.

Dawson, J.W. (1992). Myrtaceae: Leptospermoideae. In: Morat, P. \& H.S. MacKee (ed.), Fl. Nouvelle-Calédonie et Dépendances 18.

Dawson, J.W. (1999). Myrtaceae, Myrtoideae I: Syzygium. In: Morat, P. (ed.), Fl. Nouvelle-Calédonie et Dépendances 23.

Govaerts, R., M. Sobral, P. Ashton, F. Barrie, B.K. Holst, L.L. Landrum, K. Matsumoto, F.F. Mazine, E. Nic Lughadha, C. Proença, L.H. Soares-Silva, P.G. Wilson \& E. Lucas (2008). World checklist of Myrtaceae. Royal Botanic Gardens, Kew.

Ibanez, T., J. Munzinger, G. Dagostini, V. Hequet, F. Rigault, T. Jaffré \& P. Birnbaum (2014). Structural and floristic diversity of mixed tropical rain forest in New Caledonia: new data from the New Caledonian Plant Inventory and Permanent Plot Network (NC-PIPPN). Appl. Veg. Sci. 17: 386-397.

IUCN (2012). IUCN Red List Categories and Criteria: version 3.1. $2^{\text {nd }}$ ed. IUCN Species Survival Commission, Gland \& Cambridge.

Landrum, L.R. \& M.L. Kawasaki (1997). The genera of Myrtaceae in Brazil: an illustrated synoptic treatment and identification keys. Brittonia 49 : 508-536.

Lucas, E.J., S.A. Harris, F.F. Mazine, S.R. Belsham, E.M. Nic Lughadha, A. Telford, P.E. Gasson \& M.W. Chase (2007). Suprageneric phylogenetics of Myrteae, the generically richest tribe in Myrtaceae (Myrtales). Taxon 56:1105-1128.

Mazine, F.F., V.C. Sousa, M. Sobral, F. Forest \& E. Lucas (2014). A preliminary phylogenetic analysis of Eugenia (Myrtaceae: Myrteae), with a focus on Neotropical species. Kerw Bull. 69:1-14.

McNeILl, J. (2014). Holotype specimens and type citations: general issues. Taxon 63 : 1112-1113.

Morat, P., T. Jaffré, F. Tronchet, J. Munzinger, Y. Pillon, J.-M. Veillon \& M. Chalopin (2012). Le référentiel taxonomique Florical et les caractéristiques de la flore vasculaire indigène de la Nouvelle-Calédonie. Adansonia ser. 3, 34:177-219.
Mori, S.A., B.M. Boom, A.M. Carvalino. \& T.S. Santos (1983). Ecological importance of Myrtaceae in an eastern Brazilian wet forest. Biotropica $15: 69-70$.

Scotт, A.J. (1980). Notes on Myrtaceae in the Mascarenes with some recombinations for taxa from Aldabra, Malaya, New Caledonia. Kew Bull. 43: 473-498.

Snow, N. (2008). Studies of Malagasy Eugenia (Myrtaceae) - I: Two new species from the Masoala Peninsula and generic transfers from Monimiastrum. Syst. Bot. 33: 343-348.

Snow, N. (2011). Studies of Malagasy Eugenia (Myrtaceae) - II : Four new species, including one eaten by black lemurs on Nosy Be. Syst. Bot. 36: 677-689.

Snow, N., M.W. Callmander \& P.B. Phillipson (2015). Studies of Malagasy Eugenia - IV: Seventeen new endemic species, one new combination, and three lectotypifications; with comments on emerging distributional, ecological and evolutionary patterns. PhytoKeys 49: 59-121.

Snow, N., G.P. Guymer, \& G. Sawvel (2003). Systematics of Austromyrtus, Lenwebbia, and the Australian species of Gossia (Myrtaceae). Syst. Bot. Monogr. 65.

Snow, N., J. McFadden, T. Evans, A. Salywon, M.F. Wojciechowsкi \& P. G. Wilson (2011). Morphological and molecular evidence of polyphyly in Rhodomyrtus (Myrtaceae: Myrteae). Syst. Bot. 36: 390-404.

Snow, N., J. Rabenantoandro, F. Randriatifika, D. Rabehevitra, N.D. Razafimamonjy \& S. Cable (2012). Studies of Malagasy Eugenia (Myrtaceae) - III : Seven new species of high conservation concern from the eastern littoral forests. Phytotaxa $48: 39-60$.

Sobral, M., J.A.E. Faria Jr., M.U. Ibrahim, E J. Lucas, D. Rigueira, A. Stadnik \& D. Villaroel (2015). Thirteen new Myrtaceae from Brazil. Phytotaxa 224: 201-231.

van Wyk, A.E. \& T.K. Lowrey (1988). Studies on the reproductive biology of Eugenia L. (Myrtaceae) in Southern Africa. Monogr. Syst. Bot. Missouri Bot. Gard. 25 : 279-293. 